\title{
Distribution of erythrocyte binding antigen 175 (EBA-175) alleles and ABO blood groups in a hypoendemic area in Senegal
}

\author{
Aida S Badiane ${ }^{1,2}$, Ousmane Sarr ${ }^{2}$, Awa Bineta Deme ${ }^{2}$, Ambroise D Ahouidi $^{2}$, Papa Elhadji Omar \\ Gueye $^{2}$, Mouhamadou Ndiaye, Mame Cheikh Seck, Mouhamadou Diallo, Amy K Bei ${ }^{3}$, Manoj T \\ Duraisingh $^{3}$, Dyann Wirth ${ }^{3}$, Daouda Ndiaye ${ }^{1}$, Omar Ndir $^{1}$, Souleymane Mboup ${ }^{1-2}$ \\ ${ }^{1}$ Department of Parasitologie-Mycologie, Universite Cheikh Anta Diop de Dakar, Dakar, Senegal \\ ${ }^{2}$ Molecular Biology Unit, Malaria Section, Laboratoire de Bacteriologie virologie, Hopital A. Le Dantec, BP 7325, \\ Dakar, Senegal \\ ${ }^{3}$ Department of Immunology and Infectious Diseases, Harvard School of Public Health, \\ Boston, MA, USA
}

\begin{abstract}
Introduction: The study was conducted to determine for the first time the association between the erythrocyte binding antigen 175 (EBA-175) alleles and $\mathrm{ABO}$ blood groups in malaria patients living in Thies, a hypoendemic area in Senegal.

Methodology: In 2007, the EBA-175 alleles and blood group types were determined by nested PCR and the Simonin test respectively in blood samples obtained from uncomplicated Plasmodium falciparum malaria positive patients.

Results and conclusion: In total, 129 patients were enrolled in the study. The EBA-175 genotyping showed a prevalence of $67.45 \%$ for the Fallele, $27.90 \%$ for the $\mathrm{C}$-allele and $4.65 \%$ of mixed $\mathrm{C}+\mathrm{F}$ infection. The distribution of the ABO blood group type showed $59.8 \%$ for the $\mathrm{O}$ group, $19.7 \%$ for the A group, $17.2 \%$ for the B group, and 3.3\% for the AB group. No correlation was noted between the EBA-175 alleles and either the blood group type or parasitemia.
\end{abstract}

Key words: Plasmodium falciparum; EBA-175; blood groups; Thies; Senegal

J Infect Dev Ctries 2012; 6(10):727-733.

(Received 05 February 2012 - Accepted04 June 2012)

Copyright (c) 2012 Badiane et al. This is an open-access article distributed under the Creative Commons Attribution License, which permits unrestricted use, distribution, and reproduction in any medium, provided the original work is properly cited.

\section{Introduction}

Despite the enormous efforts in the fight against malaria through the tentative development, of vaccines or new drugs, the disease is still a public health concern. The parasite's life cycle is complex both in vertebrate hosts and Anopheles. In humans there is an asymptomatic pre-erythrocyte stage followed by an erythrocytic phase, which is responsible for the clinical symptoms. This step begins with the invasion of red blood cells by the merozoites, which is a rapid process governed by molecular interactions between the merozoite and the red blood cell. This interaction involves parasite ligands and receptors on the erythrocyte surface and several pathways have been identified as being used during the invasion process. The main sialic acid dependent pathway uses EBA175 in the merozoite and glycoprhorin $\mathrm{A}$ in the red blood cell. EBA-175 is divided into seven regions classified from I to VII [1] (Figure 1). Region III of EBA-175 contains either F (FCR3 strain) or C (Camp strain) segments that define dimorphic allelic family sequences [2].

The major difference between the two dimorphic proteins is the presence of a small defined set of amino acid residues. The Camp EBA-175 protein contains a 113-amino-acid-residue domain called the $\mathrm{C}$ segment, and the FCR-3 EBA-175 protein a 139-residue domain designated as the $\mathrm{F}$ segment [2]. These domains are also involved in the interaction between the merozoite and the red blood cell. Although they do not possess significant sequence homology, when expressed in vitro, they both bind to erythrocytes in a sialic acidindependent manner and contain cross-reactive epitopes [3].

Thus it is very important to study the interaction between merozoites and red blood cells. In clinical practice, the $\mathrm{ABO}$ system is best known for blood compatibility studies and has been the subject of several investigations of its association with infectious and non-communicable diseases [4,5]. The 
Figure 1. Erythrocyte binding 175 (EBA-175) domains

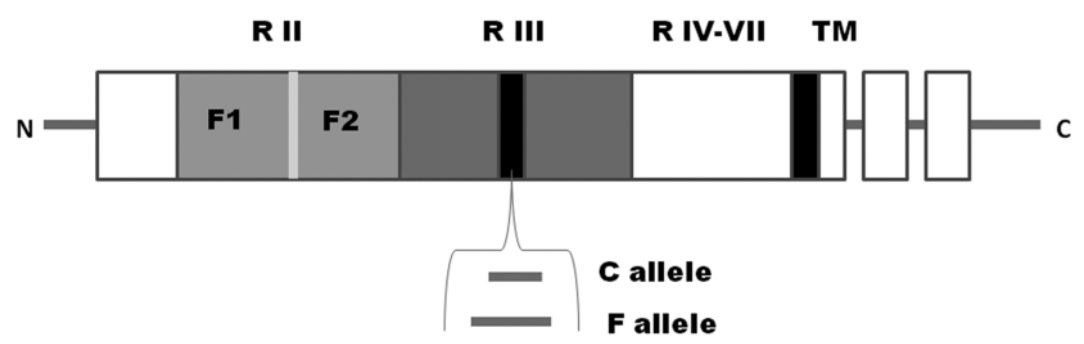

relationships between blood group distribution and malaria, and between $\mathrm{ABO}$ and malaria, have been suggested for decades [6].

Studies have shown that group $\mathrm{O}$ subjects have protection against severe malaria [7-9].

A study in Sri Lanka showed strong statistical evidence of an association between $\mathrm{ABO}$ and disease severity in Plasmodium falciparum infection [10]. It has been shown that Plasmodium falciparum form larger, stronger rosettes in non $\mathrm{O}$ blood groups (A, B, $\mathrm{AB})$ than in group $\mathrm{O}$ erythrocytes [11]. Interestingly, some strains of $P$ falciparum preferentially trigger rosette formation depending on the red blood group [12].

Furthermore, an especially high prevalence of group $\mathrm{O}$ coupled with a low prevalence of group $\mathrm{A}$ is found throughout sub-Saharan Africa, where $P$. falciparum persists to this day. It appears that the A and $\mathrm{B}$ antigens are receptors for rosetting on uninfected red blood cells [13], because they are bound by a parasite protein called PfEMP1 which is expressed on the surface of infected red blood cells [14]. Rosettes still form in group O red blood cells (albeit smaller and weaker than those that form in non$\mathrm{O}$ red blood cells) through the involvement of other red blood cell molecules which act as alternative receptors for rosetting. Consequently, the contribution of the ABO blood group system to malaria infection must be investigated further.

Our goal was to determine for the first time the distribution of EBA-175 alleles and ABO blood group in Thies, a hypoendemic area in Senegal.

\section{Methodology}

\section{Patients}

Patients were recruited in Thies, Senegal, a hypoendemic area located 70 kilometers from Dakar.
The study was approved by the IRB of the Harvard School of Public Health and the Comite d'ethique du Senegal.

Samples were obtained from patients with uncomplicated malaria during the 2007 transmission season (October to December). Informed consent was obtained from the participants and parents or guardians of all participating children. All participants monitored were screened for Plasmodium falciparum infection by light microscopy. Blood was collected by venipuncture using EDTA Vacutainer tubes Tyco Healthcare Group Lp, Mansfield, USA) for the determination of blood groups. Blood was spotted on Whatman filter paper and dried at room temperature for the extraction of $P$. falciparum DNA. Filter papers were sealed in plastic bags with silica gel until DNA extraction. Thick and thin blood films were Giemsastained and examined with a light microscope, and parasitemia was determined as percentage of infected cells. Socio-demographics and clinical data such as age, sex, parasitemia, axillary temperature, hemoglobin level, and hematocrit were also recorded. All participants diagnosed with $P$. falciparum malaria were treated based on the National Malaria Program recommendations. The study population was divided into two groups: under 10 years, and over 10 years of age.

\section{DNA extraction}

Parasite DNA was extracted from dried blood spots by using the QIAmp DNA mini kit (Quiagen, Hilden Germany) by following the manufacturer's instructions.

\section{EBA-175 genotyping}

The typing was performed by nested PCR as described elsewhere [15]. The outcome of the 
Figure 2. Distribution of EBA-175 alleles

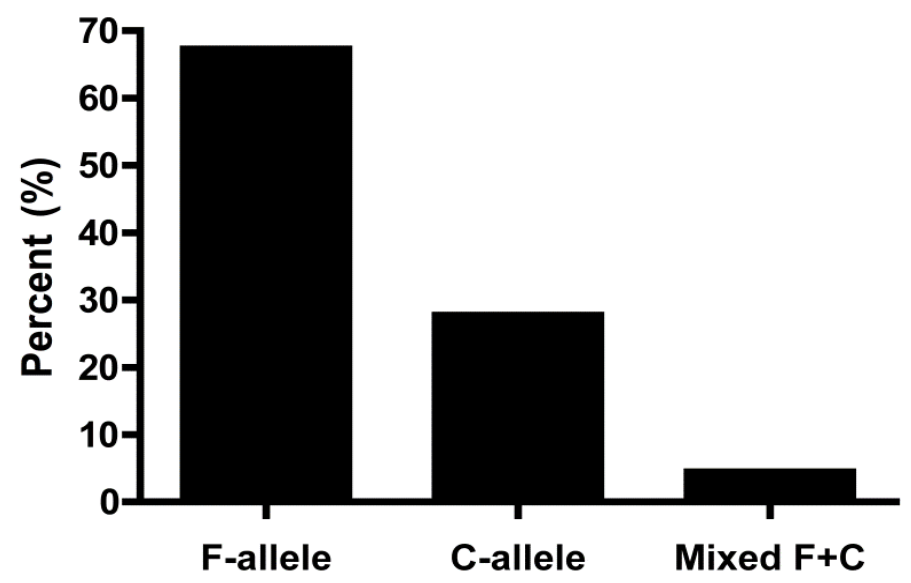

amplification was controlled by electrophoresis in an ethidium bromide-stained $1 \%$ agarose gel. For detection of the stained DNA, an ultraviolet transluminator and specific detection software was used. A PCR product at 795 bp indicated an infection with the F-fragment while a band at 714 bp showed an infection with the $\mathrm{C}$-fragment. The presence of two bands at 795 and 714 respectively indicated a mixed infection of the patient with at least two different parasite clones.

\section{Blood group typing}

Blood groups were determined using the Simonin method, which is an erythrocyte test for identifying circulating plasmatic antibodies. The patient's serum or plasma containing the potential circulating antibodies was mixed with A red blood cells and B red blood cells and agglutination was recorded. The blood group was determined by lack of agglutination (a lack of antibodies to that blood group).

\section{Statistical analyses}

Analyses were performed using statistical packages SPSS 16.0 (IBM, Chicago, USA) and STATA 11.0 (StataCorp, College Station, TX, USA). Statistical Student's T test was considered significant if $\mathrm{P}$ values were $<0.05$.

\section{Results}

Frequencies of EBA-175 genotypes and ABO blood groups in the population

A total of 129 patients were enrolled in our study, and $38 \%$ of them were female. The majority of the study population $(85 \%)$ was older than 10 years of age. Parasitemia varied between $0.1 \%$ to $12.5 \%$ with a mean of $2.2 \pm 0.4$. A significant negative correlation was found between age and parasitemia $(\mathrm{P}=0.011)$. The EBA-175 genotyping showed that $67.5 \%$ of the 129 patients carried the F-fragment, $27.9 \%$ carried the $\mathrm{C}$-fragment, and $4.6 \%$ carried $\mathrm{C}-\mathrm{F}$ mixed infections (Figure 2). As shown in Figure 3, among the 122 participants whose blood types were determined, the $\mathrm{O}$ group was the most prevalent (59.8\%), followed by the A group (19.7\%), the B group (17.2\%) and the $\mathrm{AB}$ group (3.3\%).

\section{EBA-175 alleles and blood groups}

In patients with blood group $\mathrm{O}$, we observed the following frequencies of EBA-175 alleles: 67\% Ffragment, 27\% $\mathrm{C}$-fragment and 6\% mixed infection (F-C). For patients with blood group A, we observed 63\% F-fragment and 37\% C-fragment and no mixed infections. In patients with blood group B we observed $71 \%$ F-fragment, $19 \% \mathrm{C}$-fragment and $10 \%$ mixed infection. In the AB blood group we observed $75 \%$ Ffragment, $25 \% \mathrm{C}$-fragment and no mixed infections (Figure 4).

\section{EBA-175 alleles and age}

The F-fragment was predominant in both age groups, at $80 \%$ for patients under 10 years of age and $65.14 \%$ for participants 10 years or older. Mixed infections with the presence of both alleles were noted only in the age group younger than 10 years, but there were only six samples $(5.5 \%$. There was no correlation between the allele distribution and age group. 
Figure 3. Blood group distribution

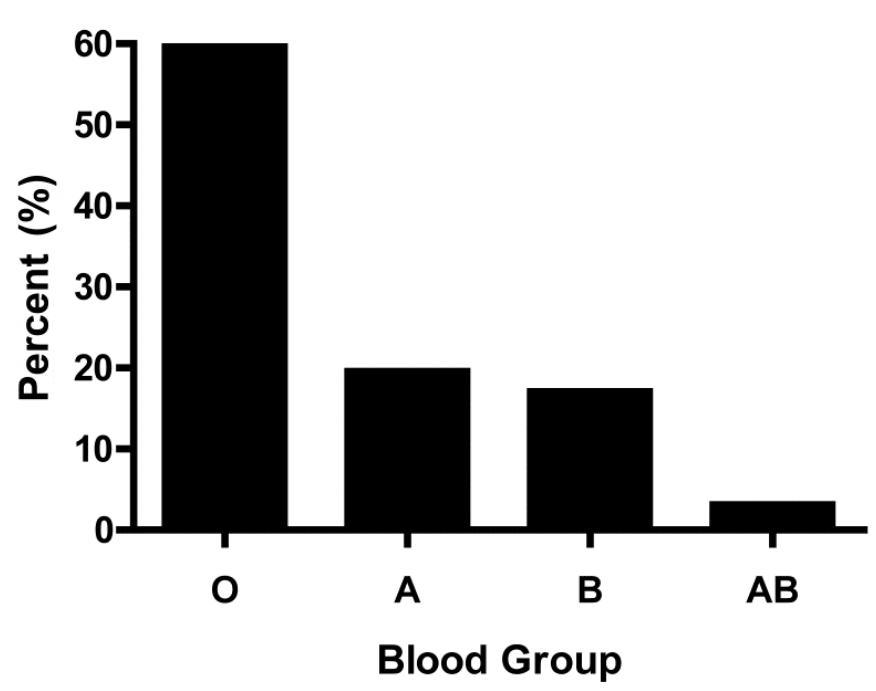

EBA-175 alleles and temperature, parasitemia, sex

Axillary temperature was measured for all patients and ranged from $37^{\circ} \mathrm{C}$ to $42^{\circ} \mathrm{C}\left(38.8^{\circ} \mathrm{C} \pm 0.3^{\circ} \mathrm{C}\right)$.

There was no correlation between parasitemia and temperature. Similarly there were no correlations between EBA-175 alleles and age, sex or parasitemia.

\section{Discussion}

The invasion of erythrocytes by malarial merozoites is a complex process [16,17] that involves multiple steps and interactions with ligand receptors. Erythrocyte binding antigen 175 (EBA-175) of $P$. falciparum is one of the key components during the fast cascade of interactions between the parasite and host molecules before the merozoite completely invades the erythrocytes [18]. To detect the alleles of EBA 175 (F-fragment and C-fragment) and to map their distribution in Thies, a nested PCR method was used.

The results showed the presence of the two alleles with a predominance of the F-fragment $(67.45 \%)$. Similarly, in Bakoumba, Gabon, the F-fragment was more prevalent in children [19]. Similar frequencies were also described in Nigeria, The Gambia, Gabon, and South Africa [20]. Outside of Africa, the Ffragment was also predominant in Northern Laos [21] and in Iran [22]. However, in Sudan, the C-fragment was the dominant allele in the population [20]. In Southern Laos, a study showed an almost equal distribution of the two fragments [21]. Surprisingly, our findings show a higher prevalence of the $\mathrm{F}$ allele which is different from observations previously described in two studies in Senegal [23,24]. This discrepancy might be attributed to the fact that our study site is a low endemic area, compared to those other sites (Velingara and Kaolack). A study conducted in Ghana in children with severe malaria showed a predominance of the F-fragment and it was noted that the $\mathrm{C}$-segment was significantly associated with fatal outcome [25]. Our results taken together with these studies demonstrate that the distribution of EBA-175 alleles is different across geographic regions. According to Binks et al., genetic differences in the human host population may be a reason for allelic selection [20], while Okenu et al. have shown that antibodies against $\mathrm{C}$ or $\mathrm{F}$ alleles can be heterologous or homologous [26].

The interaction between the merozoite and the red blood cell is essential for invasion. While some ligand/receptor pairs have been identified, many remain to be discovered [27,28].

The ABO blood group system is arguably the best known blood group system on the erythrocyte, and yet the most functionally mysterious genetic polymorphism in humans. The relationship between the $\mathrm{ABO}$ system and diseases has been studied for many years, especially the association between malaria and ABO [29], because of the critical interaction between the Plasmodium parasite and the red blood cells. 
Figure 4. Blood group type and EBA-175 alleles

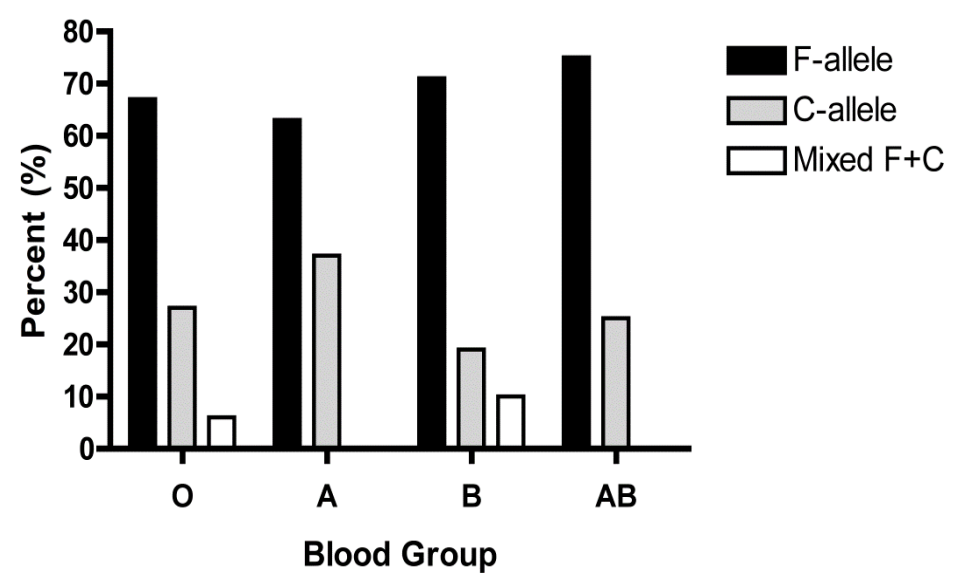

In our study, subjects with blood group $\mathrm{O}$ represented $59.8 \%$ of the population, which is the case in most countries in the western hemisphere, where the distribution of group $\mathrm{A}$ and Group $\mathrm{O}$ generally matches malaria's tropical distribution [30]. In fact, in the general population in Senegal, we note a prevalence of group $\mathrm{O}$ of $50 \%$ against $25 \%$ for the group A (Badiane et al. unpublished data).

It is believed that the distribution of the $A B O$ blood system alleles in Africa was influenced by Plasmodium selective pressure [30,31]. The distribution of blood groups shows that group $\mathrm{O}$ is relatively more represented in countries where malaria is prevalent. In regions where the disease is or was endemic, blood group $\mathrm{O}$ represents the majority type, such as in Southeast Nigeria (87.60\%), Kenya/Kiyuki (60\%), and Central America/Amazon basin (90\%). In contrast, in areas without malaria, such as Sweden (62\%), Switzerland (60\%), the Czech Republic (70\%), and Portugal (65\%), the non-O blood groups represent the majority. In Asia, the prevalence of group $\mathrm{O}$ rises among people who live closer to the equator. For example, in China, the prevalence for group O is $29 \%$ in Beijing (a cold weather zone), but it is $46 \%$ in Canton, which is a more tropical zone [30]. Many studies have focused on the association between malaria and blood groups, and have shown that individuals who belong to group $\mathrm{O}$ are protected against severe malaria [32,33,11,34-37]. Thus if survival from malaria is associated with group $\mathrm{O}$, then the worldwide distribution of $\mathrm{ABO}$ groups is consistent with malaria selective pressure.

The repartition of the EBA-175 alleles according to blood group showed a predominance of the F- segment in each blood group type. Mixed infections were noted in the groups $\mathrm{O}$ and $\mathrm{B}$. In the $\mathrm{AB}$ group, no mixed infections was noted, but the low representation of the $\mathrm{AB}$ blood group may be the reason $(<5 \%, \mathrm{n}=$ 4). Our study population was composed of uncomplicated malaria patients, making it impossible to determine a relation between EBA-175 alleles, blood groups, and the severity of the infection. There were no correlations between any of the two EBA-175 alleles and sex, parasitemia, temperature, or age.

Our results showed that parasitemia is negatively correlated with age $(P=0.011, P<0.05)$. In endemic areas, most individuals develop an immune response that controls the parasite replication but does not eliminate the parasite from blood. Numerous epidemiological studies conducted in areas of stable malaria transmission report an age-dependent increase in Plasmodium-specific immune responses, as well as an age-related decrease in malaria-dependent morbidity [38]. This immunity is naturally acquired and is (i) effective in adults after uninterrupted lifelong heavy exposure; (ii) lost upon cessation of exposure; (iii) species specific; (iv) somewhat stage specific; and (v) acquired at a rate which is dependent upon the degree of exposure [39-42].

EBA-175 is an important ligand interacting with the sialic acid of glycophorin A and permits the parasite to invade the red blood cell. The interaction between the Plasmodium parasite and the erythrocyte involves region RIII, and the role of this dimorphism in the host-parasite interactions, such as the difference in efficiency of red blood cell invasion related to genotype, remains unclear. Understanding the 
mechanisms involved in this step can lead to strategies to control malaria.

\section{Acknowledgements}

We would like to thank Lamine Ndiaye, Younous Diedhiou, and the study participants from whom blood samples were collected.

Aida Sadikh Badiane is a Fogarty trainee supported by the National Institute of Health grant 5D43TW001503-09 to Dr. Dyann Wirth.

\section{References}

1. Adams JH, Sim BK, Dolan SA, Fang X, Kaslow DC, Miller LH (1992) A family of erythrocyte binding proteins of malaria parasites. Proc Natl Acad Sci USA 89: 7085-7089.

2. Ware LA, Kain KC, Lee Sim BK, Haynes JD, Baird JK, Lanar DE (1993) Two alleles of the 175-kilodalton Plasmodium falciparum erythrocyte binding antigen. Mol Biochem Parasitol 60: 105-109.

3. Kain KC, Orlandi PA, Haynes JD, Sim KL, Lanar DE (1993) Evidence for twostage binding by the $175-\mathrm{kD}$ erythrocyte binding antigen of Plasmodium falciparum. J Exp Med 178: 1497-1505.

4. Moulds JM, Moulds JJ (2000) Blood group associations with parasites, bacteria and viruses. Transfusion Med Rev 14: 302311.

5. Airds I, Bentall HH, Roberts JAF (1953) A relationship between cancer of the stomach and the $\mathrm{ABO}$ blood groups. $\mathrm{Br}$ Med J 1: 799-801.

6. Athreya BH and Coriell LL (1967) Relation of blood groups to infection: Aa survey and review of data suggesting possible relationship between malaria and blood groups. Am J Epidemiol 86: 292-304.

7. Fischer PR and Boone P (1998) Short report: Severe malaria associated with blood group. Am J Trop Med Hyg 58:122123.

8. Lell B, May J, Schmidt-Ott RJ, Lehman LG, Luckner D, Greve B, Matousek P, Schmid D, Herbich K, Mockenhaupt FP, Meyer CG, Bienzle U, Kremsner PG (1999) The role of red blood cell polymorphisms in resistance and susceptibility to malaria. Clin Infect Dis 28: 794-799.

9. Loscertales M-P and Brabin BJ (2006) Phenotypes and malaria related outcomes in mothers and babies in The Gambia: a role for histo-blood groups in placental malaria? Malaria J 5: 1-6.

10. Pathirana SL, Alles HK, Bandara S, Phone-Kyaw M, Perera MK, Wickremasinghe AR, Mendis KN, Handunnetti SM (2005) ABO blood-group types and protection against severe Plasmodium falciparum malaria. Ann Trop Med Parasitol 99: 119-124.

11. Carlson J, Wahlgren M (1992) Plasmodium falciparum erythrocyte rosetting is mediated by promiscuous lectin-like interactions J Exp Med 176: 1311-1317.

12. Barragan A, Klremsssner PG, Wahlgre M, Carlson J (2003) Blood group A antigen as a coreceptor in $P$. falciparum parasites. J Infect Dis 188: 153-164.

13. Barragan A, Kremsner PG, Wahlgren M, Carlson J (2000) Blood group A antigen is a coreceptor in Plasmodium falciparum rosetting. Infect Immun 68: 2971-2975.

14. Chen Q, Heddini A, Barragan A, Fernandez V, Pearce SF, Wahlgren M (2000) The semiconserved head structure of Plasmodium falciparum erythrocyte membrane protein 1 mediates binding to multiple independent host receptors. J Exp Med 192: 1-10.

15. Touré FS, Mavoungou E, Ndong JM, Tshipamba P, Deloron P (2001) Erythrocyte binding antigen (EBA-175) of Plasmodium falciparum: improved genotype determination by nested polymerase chain reaction. Trop Med Int Health 6: 767-769.

16. Cowman AF and Crabb BS (2006) Invasion of red blood cells by malaria parasites. Cell 124: 755-766.

17. Gaur D, Mayer DC, Miller LH (2004) Parasite ligand-host receptor interactions during invasion of erythrocytes by Plasmodium merozoites. Int J Parasitol 34: 1413-1429.

18. Barnwell JW and Galinski MR (1998) Invasion of vertebrate cells: erythrocytes. In Sherman IW (ed.) Malaria: parasite biology, pathogenesis and protection. Washington DC, ASM Press. p. 93-120.

19. Toure FS, Bisseye C, Mavoungou E (2006) Imbalanced distribution of Plasmodium falciparum EBA-175 genotypes related to clinical status in children from Bakoumba, Gabon. Clin Med Res 4: 7-11.

20. Binks RH, Baum J, Oduala AMJ, Arnaud E, Babiker HA, Kremsner PG, Roper C, Greenwood BM, Conway DJ (2001) Population genetic analysis of the Plasmodium falciparum erythrocyte binding antigen-175 (eba-175) gene. Molecular \& Biochemical Parasitology 114: 63-70.

21. Dittrich S, Schwobel B, Jordan S, Vanisaveth V, Rattanaxay P, Christophel EM, Phompida S, Jelinek T (2003) Distribution of the two forms of Plasmodium falciparum erythrocyte binding antigen-175 (eba-175) gene in Lao PDR. Malar J 2: 23.

22. Heidari A, Keshavarz H, Dittrich S, Jelinek T (2009) Allelic dimorphism of the Plasmodium falciparum Erythrocyte Binding Antigen-175 (EBA-175) Gene in the Southeast of Iran. Iranian J Parasitol 4: 17-22.

23. Soulama I, Bigoga JD, Ndiaye M, Bougouma EC, Quagraine J, Casimiro PN, Stedman TT, Sirima SB (2011) Genetic diversity of polymorphic vaccine candidate antigens (Apical Membrane Antigen-1, Merozoite Surface Protein-3, and Erythrocyte Binding Antigen-175) in Plasmodium falciparum Isolates from Western and Central Africa. Am J Trop Med Hyg 84:276-284.

24. Ahouidi A, Bei AK, Neafsey DE, Sarr O, Volkman S, Milner D, Cox-Singh J, Ferreira MU, Ndir O, Premji Z, Mboup S, Duraisingh MT (2010) Population genetic analysis of large sequence polymorphisms in Plasmodium falciparum bloodstage antigens. Infect Genet Evol 10: 200-206.

25. Cramer JP, Mockenhaupt FP, Möhl I, Dittrich S, Dietz E, Otchwemah RN, Ehrhardt S, Bienzle U, Jelinek T (2004) Allelic dimorphism of the erythrocyte binding antigen-175 (eba-175) gene of Plasmodium falciparum and severe malaria: Significant association of the C-segment with fatal outcome in Ghanaian children. Malar J 3: 11.

26. Okenu DM, Riley EM, Bickle QD, Agomo PU, Barbosa A, Daugherty JR, Lanar DE, Conway DJ (2000) Analysis of human antibodies to erythrocyte binding antigen 175 of Plasmodium falciparum. Infect Immun 68: 5559-5566.

27. Tham WH, Wilson DW, Lopaticki S, Schmidt CQ, TettehQuarcoo PB, Barlow PN, Richard D, Corbin JE, Beeson JG, Cowman AF (2010) Complement receptor 1 is the host erythrocyte receptor for Plasmodium falciparum PfRh4 invasion ligand. PNAS 107: 17327-17332 
28. Crosnier C, Bustamante LY, Bartholdson SJ, Bei AK, Theron M, Uchikawa M, Mboup S, Ndir O, Kwiatkowski DP, Duraisingh MT, Rayner JC, Wright GJ (2011) Basigin is a receptor essential for erythrocyte invasion by Plasmodium falciparum. Nature 480: 534-537.

29. Uneke CJ (2007) Plasmodium falciparum malaria and ABO blood group: is there any relationship? Parasitol Res 100: 759-765.

30. Cserti CM and Dzik WH (2007) The ABO blood group system and Plasmodium falciparum malaria American Society of Hematology 110: 2250-2258.

31. Mourant AE, Kopec AC, Domaniewska-Sobczak K (1976) The Distribution of the Human Blood Groups and other Polymorphisms. 2nd ed. Oxford University Press, London, pp. 705-709.

32. Rowe A, Obeiro J, Newbold CI, Marsh K (1995) Plasmodium falciparum rosetting is associated with malaria severity in Kenya. Infect Immun; 63: 2323-2326.

33. Fry AE, Griffiths MJ, Auburn S, Diakite M, Forton JT, Green A, Richardson A, Wilson J, Jallow M, Sisay-Joof F, Pinder M, Peshu N, Williams TN, Marsh K, Molyneux ME, Taylor TE, Rockett KA, Kwiatkowski DP (2008) Common variation in the ABO glycosyl-transferase is associated with susceptibility to severe Plasmodium falciparum malaria. Hum Mol Genet 17: 567-576.

34. Udomsangpetch R, Todd J, Carlson J (1993) The effects of hemoglobin genotype and $\mathrm{ABO}$ blood group on the formation of rosettes by Plasmodium falciparum-infected red blood cells. Am J Trop Med Hyg 48: 149-153.

35. Rowe JA, Handel IG, Thera MA, Deans AM, Lyke KE, Koné A, Diallo DA, Raza A, Kai O, Marsh K, Plowe CV, Doumbo OK, Moulds JM (2007) Blood group O protects against severe Plasmodium falciparum malaria through the mechanism of reduced rosetting. Proc Natl Acad Sci USA 104: 17471-17476.

36. Jallow M, Teo YY, Small KS, Rockett KA, Deloukas P, Clark TG, Kivinen K, Bojang KA, Conway DJ, Pinder M, Sirugo G, Sisay-Joof F, Usen S, Auburn S, Bumpstead SJ, Campino S, Coffey A, Dunham A, Fry AE, Green A, Gwilliam R, Hunt SE, Inouye M, Jeffreys AE, Mendy A, Palotie A, Potter S, Ragoussis J, Rogers J, Rowlands K, Somaskantharajah E, Whittaker P, Widden C, Donnelly P, Howie B, Marchini J, Morris A, SanJoaquin M, Achidi EA, Agbenyega T, Allen A, Amodu O, Corran P, Djimde A, Dolo A, Doumbo OK, Drakeley C, Dunstan S, Evans J, Farrar J, Fernando D, Hien
TT, Horstmann RD, Ibrahim M, Karunaweera N, Kokwaro G, Koram KA, Lemnge M, Makani J, Marsh K, Michon P, Modiano D, Molyneux ME, Mueller I, Parker M, Peshu N, Plowe CV, Puijalon O, Reeder J, Reyburn H, Riley EM, Sakuntabhai A, Singhasivanon P, Sirima S, Tall A, Taylor TE, Thera M, Troye-Blomberg M, Williams TN, Wilson M, Kwiatkowski DP; Wellcome Trust Case Control Consortium; Malaria Genomic Epidemiology Network (2009) Genomewide and fine-resolution association analysis of malaria in West Africa. Nat Genet 41: 657-665.

37. Deepa, Vanamala A. Alwar, Karuna Rameshkumar and Cecil Ross (2011) ABO blood groups and malaria related clinical outcome. J Vector Borne Dis 48: 7-11.

38. Warsame M, Wernsdorfer WH, Perlmann H, Lebbad M, Ericsson O, Matola YG, Troye-Blomberg M, Perlmann P, Berzins K (1997) A malariometric survey in a rural community in the Muheza district, Tanzania: age profiles in the development of humoral immune responses. Acta Trop 68: 239-253.

39. Schuffner, WAP (1919) Two subjects relating to the epidemiology of malaria. Mededeelingen van der Burgerlijken Geneeskundingen Dienst in Nederlandsche-Indie 9: 1-34.

40. Schwartz E, Sadetzki S, Murad H, Raveh D (2001) Age as a risk factor for severe Plasmodium falciparum malaria in nonimmune patients. Clin Infect Dis 33: 1774-1777.

41. Sergent E, and Parrot L (1935) L'immunité, la prémunition et la résistance innée. Arch Inst Pasteur Algerie 13: 279-319.

42. Sergente T and Sergente D (1910) Sur l'immunité dans le paludisme des oiseaux. Conservation in vitro de sporozoïtes de Plasmodium relictum. Immunité relative obtenue par inoculation de ces sporozoïtes. C R Acad Sci 151: 407.

\section{Corresponding author}

Aida Sadikh Badiane

Molecular Biology Unit, Malaria Section

Laboratoire de Bacteriologie Virologie

Hopital A. Le Dantec, BP 7325

Dakar, Senegal

Telephone: (221) 776555527 Fax: (221) 338429234

Email: abadiane@hsph.harvard.edu / asbadiane@ gmail.com

Conflict of interests: No conflict of interests is declared. 